\title{
A Co-integration Approach to the Effect of Oil Income on Resource Allocation in Iranian Economy
}

\author{
Mortaza Baky-Haskuee \\ Department of Economics, Raja University, Iran \\ E-mail: baky@email.com
}

Received: June 23, 2010 Accepted: August 18, 2010 doi:10.5539/ijef.v3n2p194

\begin{abstract}
This paper investigates the effect of oil income on real exchange rate defined as relative prices of non-tradable to tradable sector in Iranian economy. Increase in oil income, increases demand for both tradable and no-tradable goods. Tradable goods prices follow international prices while non-tradable prices are set in domestic markets. Therefore increase in oil income will result in real exchange rate appreciation and change in resource allocation in different economic sectors. Oil windfalls have changed the structure of the economy and relative prices such that the shares of agriculture and industry have decreased and the shares of services and construction have increased in GDP. The results show that there is a long run co-integration relation between oil income, capital outflow, GDP and real exchange rate.
\end{abstract}

Keywords: Oil Income, Resource Allocation, Real Exchange Rate, Co-integration, Iranian Economy

\section{Introduction}

The most important characteristic of the pre-and-post revolution Iranian economy is its dependency on oil income. The share of oil value added in national income has been 21 percent on average since 1959. It increased from 13percent in 1959 to 52 percent in 1973; the year of first oil shock. It lowest amount was 5 percent at the second oil shock and increased to 31 percent thereafter. Oil revenues are the main source of foreign exchange on one side and the main part of state income on the other side. The dependency of government budget on oil prevented establishment of a robust tax system. Government intervention in form of current and investment expenditures have important implication for relative prices and real exchange rate fluctuation. During the 1960-69, the average share of oil exports in Iranian economy was excess of 81\%. During the period 1970-79, its share in total export increased, on average, to $91.4 \%$. This increased to $98.6 \%$ during $1980-85$.It has declined to $69.9 \%$ during $1985-1990$ and it has been over 52\% thereafter. Share of oil revenue in total government revenue is also an important index of oil dominance in Iranian economy. While oil compromising about $48.2 \%$ and $67.7 \%$ of public revenue during 1963-69 and 1970-79 periods respectively, it accounted for about 30\% of total public revenue during 1986-92 and $28 \%$ thereafter up to 2006.

During last decades oil has been have a dominant role in Iranian economy. Oil had reshaped the whole economy and changed the role of public sector after it became the main source of foreign exchange and public revenue. Nationalization of oil sector in 1951 and establishment of OPEC, which increased the power of oil exporting countries in controlling oil price and production, increased the significance of oil in Iranian economy, strengthened the political power of government and increased its intervention in the process of economic development (Baky-Haskuee, 2003, Busby and etal,2002).

First oil shock, followed by dramatic Arab embargo of October 1973, which quadrupled world oil price, caused a chain of events that have a great impact on the economies of all countries; industrialized, developing oil-importing and oil exporting countries. Theoretically, positive oil shocks result in exchange rate appreciation in oil exporting countries. This research defines real exchange rate as domestic prices in terms of foreign goods. In this regard, real exchange rate appreciation continued to deviate from its pre-revolution level. In addition to this, there has been long-run movement in underlying fundamentals affecting the real exchange rate. Human and physical capital outflow, political instability, change in institutional arrangements, structural changes, economic sanctions, imposed war, political pressures and a number of exogenous variables, shift macroeconomic variables including real exchange rate. The aim of this paper is to show that, oil income fluctuations has been the main source of real exchange rate fluctuations, alongside a series of fundamental variables including capital outflow, and as a result reshaped resource allocation in Iranian economy. In this sense, oil income has been the main source of real exchange rate long-run movements. To show the effect of oil income on resource allocation in Iranian economy, we define real exchange rate as the relative price of non-tradable goods in terms of tradables. Using co-integration approach we showed that oil income is a main determinant of real exchange rate movement in Iranian economy. The rest of 
the paper constructed as follow. Second section reviews oil income effects on resource allocation in the Booming Sector tradition. The third section uses a co-integration approach to test positive effect of oil income on real exchange rate appreciation. Section four concludes the remarks.

\section{Booming Sector and Resource Allocation}

There exists a huge literature on why countries might suffer "resource curse"(Auty,1999,2001). Six transmission mechanisms can be considered- a long-term decline in terms of trade; revenue volatility; "booming Sector theories"; crowding out effects; increasing the role of the state; and finally the socio-cultural and political impacts. "Booming sector theories" focus on the impact of a booming sector on resource allocation in the rest of the economy. The most widespread theoretical explanation of this apparent puzzle is found in models of the Dutch disease, where resource abundance shifts factors of production away from tradable sectors. Studies by Van Wijnbergen (1984), Krugman (1987), Matsuyama (1992), Sachs and Warner (1995) and Gylfason et al. (1999) finding show that the exploitation of more natural resources shrinks the traded (industrial and agricultural) sectors, and thus total factor productivity across the economy reduces. This literature has been most influential in explaining why resource wealth may lower growth.

Positive oil price socks increase real income. These shocks have two main effects; expenditure effect and factor movement effect. In the resource movement effect, the resource boom will increase factor productivity in leading sector which increases the demand for labor. Factor productivity growth causes factor of production to shift toward the booming sector away from the lagging sectors i.e. industry and agriculture. This shift in factors from the lagging sector to the booming sector is called direct de-industrialization and direct de-aggriculturalization. However, this effect can be negligible, since the hydrocarbon and mineral sectors generally are capital intensive. Spending effect which is called indirect-deindustrialization and de-aggriculturalization occurs as a result of the extra revenue brought in by the resource boom. It shifts factors of production away from the tradable sector into non-tradable sector. As a result of the increased real income, demand both tradable and non-tradable shift up. While the prices in the traded good sector follow the rule of one price, and set internationally, non-tradable price and demand determined in domestic markets. So as a result of real income increase, non-tradable prices increase in terms of tradable prices. This profitability increase of non-tradable sector, translated into real exchange rate appreciation. Facing an appreciated exchange rate, resources flow to the more profitable productive sectors, that is the booming sector and non tradable, and demand shifts to inexpensive imports. This is what is known as the "Dutch disease," in reference to appreciation of the real exchange rate in the Netherlands when it started to export large quantities of North Sea natural gas (Cordon,1984).

In many cases, the sector most affected by this changing price structure has been agriculture. Industrial sectors have often been protected by tariffs and import restrictions in partial compensation for appreciation of the real exchange rate. Again, this equilibrium reflects the new comparative advantage of the country producing the booming commodity, yet it implies important restructuring of the whole economy. Furthermore, if, as in the case of oil, the sudden price boom is of short duration, economies find themselves with dismantled tradable sectors at the onset of the downturn of the Dutch disease. Only a few farsighted countries, like Cameroon or Botswana (Hill, 1991), protected themselves against such costly fluctuations by sterilizing foreign earnings abroad and regulating their entry into the country. This avoided an appreciation in the real exchange rate and saved foreign resources for times beyond the short commodity boom. Other mechanisms that can be used to prevent appreciation of the real exchange rate include increased government reserves out of taxation of foreign revenues, repayment of foreign debt, and exports of capital for direct foreign investment in other countries.

\subsection{Real exchange Rate : Alternative Definitions}

Purchasing power parity theory defines the real exchange rate as

$$
R E R=\frac{p}{p^{f} e} \text {; where } p \text { and } p^{f} \text { are domestic }
$$

and foreign price indexes, and $e$ is the nominal exchange rate, defined as the domestic value of a unit of foreign currency. Note 1)

The choice of nominal exchange rate to construct real exchange rate is controversial. Pinto(1990) makes a theoretical argument that, when the official market is rationed and domestic currency is only convertible in the floating parallel market at the free rate, imports purchased with official dollars are priced in domestic currency at their opportunity cost which is the parallel market nominal exchange rate. In the next section we show that the most appropriate nominal exchange rate that can indicate change in relative prices (the appropriate nominal exchange rate for construction of real exchange rate) is parallel market nominal exchange rate. Bahmani-Oskooee (1993, p.4055) argues that the black market nominal exchange rate served as an indicator of present and future price of imported as well as domestically produced goods. Whenever the dollar was up, so were the prices of all tradable and non tradable goods. 
Alternatively, the real exchange rate can be defined as the relative price of non tradable in terms of tradable goods. Although these two definitions differ, the former is used as the proxy for later in most empirical studies (Edwards, 1989, pp.1-8) (Note 2). Then real exchange rate, defined as ${ }_{R E R}=\frac{P_{N}}{P_{T}}$, where $p_{N}$ and $p_{T}$ are non-tradable and tradable price indexes respectively defined as the ratio of value added of each sector in current prices to the value added in real (constant) prices(Note 3). To construct RER both tradable and non tradable sectors are decomposed into consumption and capital goods. Tradable capital goods include machinery and equipment and non tradable capital goods includes construction. Value added in service sector is treated as non tradable consumption goods. Services include public, social, professional, monetary and financial services, transportation and communication, hotels, restaurant and commercial activities. They include governmental services as well as. This concept simply shows change in relative prices and competitiveness of domestic tradable goods against foreign importable goods. Although the two definitions differ, the former is used as a proxy for the later in empirical studies. (Note 4)

The purchasing-power parity hypothesis in its simplest form suggests that the real exchange rate is constant at the level reached at a time of macroeconomic balance and that reversions to the mean from any observed deviations are rapid. However, empirical evidence in support of this hypothesis is limited. To explain this discrepancy, several recent studies have examined time-varying sources of fluctuation in equilibrium real exchange rates as an alternative to the purchasing-power parity hypothesis. (Note 5 )

MacDonald and Ricci (2003) and Koranchelian (2005) study the effect of resource endowments (e.g., oil discoveries), terms of trade (e.g., oil prices), real interest rates and labor productivity differentials relative to a country's trading partners, and changes that arise as a result of economic policies and other factors, but do not examine the effects of parallel market rates on the equilibrium real exchange rates.

Our assertion is that, when prices are flexible and the nominal exchange rate is frequently floating, the RER depends on the real fundamentals of the economy. Changes in real fundamentals such as log-term productivity growth, the underling capital flow, the term of trade and world economic conditions cause change in the underling demand and supply in real sector and consequently lead to change in real exchange rate. Against the proponents of purchasing power parity that believe equilibrium real exchange rate is constant, we show that it depends upon fundamentals that may change over time.

\section{A co-integration approach to the effect of oil income on real exchange rate fluctuations}

In regressing a time series variable on another time series variable(s), one often obtains a very high $R 2$ even though there is no meaningful relationship between the two variables. Sometimes we expect no relationship between two variables, yet a regression of one on the other variable often shows a significant relationship. This situation exemplifies the problem of spurious, or nonsense, regression. Empirical works based on time series data assume that the underlying time series are stationary. Broadly speaking, a stochastic process is said to be stationary if its mean and variance are constant over time and the value of the covariance between the two time periods depends only on the distance or gap or lag between the two time periods and not the actual time at which the covariance is computed. In the time series literature, such a stochastic process is known as a weakly stationary, or covariance stationary, or second-order stationary, or wide sense, stochastic proce. (Banerjee and etal, 1993).

Using non-stationary time series in a regression model lead to what Granger and Newbold (1974) called a spurious regression, and in this case statistical inference is not reliable. Therefore before estimating the model parameters, we test the existence of unit root in model's variables. Augmented Dickey-Fuller (ADF) and Phllips-Perron(PP) simple and joint tests were used to determine whether time series are stationary or not. Results for ADF and PP tests are reported in table5. 1. The results show that none of ADF and PP simple and joint test can strongly reject the null hypothesis of unit root in model's variables.

$\{$ Table 5.1$\}$

Most of non stationary economic time series are difference stationary. To test whether model's variable are trend stationary or difference stationary, we test first difference of model's variable. ADF and PP simple and joint test shows that first difference of all variables of this paper is stationary. The results are reported in table 5.2. The results show that at three interval confidence, unit root of first difference of variable strongly is rejected.

\{Table 5.2\}

Since all variable are integrated of degree one, they can be used in a regression model without fear of spurious regression. This paper uses two-step Engle-Granger co-integration test to show that there is a long run relationship between oil revenue, real GDP and capital outflow, and real exchange rate movement. In this method, first it estimates model's parameters and then checks residuals of model for unit root. If model's residual are stationary, estimated model is a non-spurious regression and there is long run co-integrating vector between model's variables. 
In the case of Iran, analysis of real exchange rate and oil shocks has been conducted from various perspectives. Using official nominal exchange rate and the consumer price index, Pesaran (1992 P.113-115) constructed indices of bilateral and effective real exchange rates for the 1960-89 period. He argued that both indecies show real appreciation after the revolution, inconsistent with the changes in fundamentals of economy .Bahmani-Oskooee (1993) used the consumer price index and the parallel market nominal exchange rate, and showed that real exchange rate was constant during 1973-1986. We hypothesize that RER movements depend on economic fundamentals. Our model to investigate RER fluctuation is as follow $R E E=\alpha_{1}+\alpha_{2} O I l+\alpha_{3} G D P+\alpha_{4} C O+\varepsilon_{t}$, where, OIL stands for oil income in US dollar, GDP is real gross domestic product in real prices, and CO stands for capital outflow in real prices(Note 6) (Note 7)

According to this model, a positive oil shock brings extra purchasing power to both public and private sector and as a result the demand for both tradable and non-tradable goods increases. The price of tradable goods id determined on world markets. Therefore, only the price of non-tradable goods will increase to restore the equilibrium in the real sector. This direct effect of oil revenue shock on RER which is called the real spending effect has different implication for public and private sectors, due to the fact that the positive oil export shocks has a huge impact on government consumption of non-tradables. Then we expect that $\alpha_{2}$ takes positive sign. Change in the domestic real income change the underling supply and demand of goods and services and consequently move the real sector of the economy out of equilibrium at the initial RER. To restore the equilibrium, the RER must adjust to the new conditions. Hence real income may have positive or negative effect. An exogenous increase in capital outflow necessitates a real exchange rate depreciation to increase equivalently the current account surplus and hence restore equilibrium in real sector. Then we expect $\alpha_{3}$ to take negative sign.

Table 5.3 show the result for a simple unilateral regression based on assumption that there is just one co-integrating vector between models variable. Based on t-statistics null hypothesis of each single coefficient can not be rejected and using $F$-Statistics, regression model is totally significant.

$\{$ Table 5.3 \}

There is a co-integrating vector between model's variables if model's residuals are stationary. ADF and PP are used to test stationarity of residuals. Both simple and joint test at three critical levels reject strongly existence of unit root in residuals, then model's residuals are stationary and hence there is one single co-integrating vector between models variables. Engle-Granger (1987) co-integration method assumption is that there is only one single co-integrating vector between variables of model. In other word it is based on assessing whether single-equation estimates of equilibrium error to be stationary. The second approach to co-integration, due to Johansen $(1988,1991)$ and Stock and Watson(1988), is based on the VAR approach. The second method is based on the assumption that, between M variables, there may be more than one co-integrating vector. On this assumption first we should test for rank of VAR and then estimate long-run parameters. Co-integration test shows that there is one co-integrating vector between model's variable. Table4,5 show the result for co-integration test. Based on $\lambda_{\max }$ test rank of VAR is one and there is one co-integrating vector between model's variables. Using maximum likelihood method, we estimate long run parameters. Normalized parameters are reported in table 5. The results show that estimated parameters of two methods are the same, and consequently there is one long run relation ship between RER, oil income, real GDP and capital outflow.

$\{$ Table 5.4$\}$

\{Table 5.5\}

In general, the results show that 90 percent of relative price movement in Iranian economy can be explained by oil revenue, capital out flow and real GDP. Also results suggest that oil revenue is the main source of resource allocation in Iranian economy. Contrary to Karshenas (1994) that assumes there is no room for Dutch disease hypothesis to explain resource allocation in Iranian economy, our results show that Dutch disease hypothesis is strongly proved in Iranian economy and beside of institutional factors, change in relative prices has reshaped resource allocation.

\section{Concluding Remarks}

Over the past decades, developing countries that are rich in natural resources have performed significantly less well in economic terms than those that are resource poor. According to existing literature, resource abundance lowers economic growth. Dutch disease models describe negative effect of oil revenues on resource allocation in exporting countries. During last decades oil has have a dominant role in Iranian economy. Oil income had reshaped the whole economy and changed the role of public sector after it became the main source of foreign exchange and public revenue. Using co-integration approach we showed that oil revenues determined relative prices in Iranian economy. The results show that contrary to purchasing power parity, real exchange rate not only is not constant, but also 
changing fundamentals such as oil income, capital outflow, that change underling demand and supply in real sector, change relative prices.

\section{References}

Auty R.M. (1999). The transition from rent-driven growth to skill-driven growth: recent experience of five mineral economies. In: Maier, J., Chambers,B., Farooq, A. (eds.) Development Policies in Natural Resource Economies, Edward Elgar, Cheltenham.

Auty R.M. (2001). Resource Abundance and Economic Development, Oxford University Press.

Bahmani-Oskooee,M.(1993). Black Market Exchange Rate Versus Official Exchange Rate in Testing Purchasing Power Parity: An Examination of the Iranian Rial, Applied Economics,vol25,(April).pp465-72.

Baky-Haskuee,Mortaza. (2003). The Effect of Oil Income on Changing Role of State in Economic Development, Paper Presented at 10th Annual Conference on Institutions and Diversity, its Role in Economic Development, Hungary, 19-23 November.

Banerjee, A., Dolado, J.W. \& Henry,D.F. (1993). Co-integration, Error-Correction, and the Econometric Analysis of Non-Stationary Data, Oxford University Press.

Busby, G., J. Isham, L. Pritchett \& M. Woolcock. (2002). The Varieties of Rentier Experience: How Natural Resource Export Structures Affect the Political Economy of Economic Growth. Mimeo, The World Bank.

Corden, W.M. \& Neary, J.p. (1982). Booming Sector and De-Industrialization in a Small Open Economy, Economic Journal,92(December), pp.825-48.

Corden, W.M. (1981). The Exchange Rate, Monetary Policy and North Sea Oil: The Economic Theory of Squeeze on Tradables, Oxford Economic Papers,33(July),23-46.

Corden, W.M. (1982). Exchange Rate Policy and Resource Boom, Economic Record,58(March),18-31.

Corden, W.M.(1984). Booming Sector and Dutch Disease Economics: Survey and Consolidation, Oxford Economic Papers, 36,pp.359-380.

Edwards,S.(1989). Real Exchange Rate, Devaluation, and Adjustment: Exchange Rate Policy in Developing Countries, Cambridge, Mass: MIT Press.

Gelb, Alan H. (1985a). The Impact of Oil Windfalls: Comparative Static with an Indonesia-like Model, World Bank Development Research Department Discussion Paper, No. DRD133.

Gelb,A.H. (1981). Capital-Importing Oil Exporters: Adjustment Issues and Policy Choices, World Bank Staff Working Paper, No.475.

Gelb,A.H. \& Associates. (1988). Oil Windfalls: Blessing or Curse? New York: Oxford University Press.

Karshenas, M. (1994). Oil, State and Industrialization in Iran, Cambridge University Press.

Koranchelian, T. (2005). The Equilibrium Real Exchange Rate in a Commodity Exporting Country: Algeria's Experience," IMF Working Paper 05/135 (Washington: International Monetary Fund).

Neary,J. \& Wijnbergen, S.V.(1986). Natural Resources and Macroeconomy: A Theoretical Framework, in Neary,J. and Wijnbergen, S.V., Natural Resources and the Macroeconomy, MIT. Cambridge, MA.

Neary,J.P.(1984). Real and Monetary Aspects of the Dutch Disease, in Jungenfeld, K.(ed.), Structural Adjustment in Developed Open Economies, London: Macmillan.

Pesaran,M.H.(1992). The Iranian Foreign Exchange Policy and The Black Market for Dollars, International Journal of Middle east Studies, Vol.24, (February),PP.101-125.

Sachs, J.D. \& A.M. Warner. (1995). Natural resource abundance and economic growth. NBER Working Paper, No. 5398.

Sachs, J.D. \&A.M. Warner (2001). The curse of natural resources. European Economic Review, vol. 45,pp. 827-838. Van Wijnbergen, S. (1984). The'Dutch disease': a disease after all? Economic Journal, Vol.94, pp. 41-55.

\section{Notes}

Note 1. In this paper by nominal exchange rate we mean us dollar in Rials.

Note 2. For alternative definition of equilibrium real exchange rate see Williamson, 1985, pp.13-20.

Note 3. The base year for construction of real prices is 2000 .

Note 4. For detail on relation between two definition see Edwards(1989), p.1-8 
Note 5. See Hinkle and Montiel (1999) for a survey of the challenges in assessing a country's equilibrium real exchange rate

Note 6. Williamson (1986) argues that the current account surplus is the mirror image of underlying capital outflow and appropriate for the estimation of effects on real exchange rate.

Note 7. The base year is 2000 , and we use GDP deflator to transform time series into real term.

Table 5.1. Unit Root Test for the Level of Variables

\begin{tabular}{|c|c|c|c|c|c|c|c|}
\hline \multirow[b]{2}{*}{ Variable } & \multicolumn{2}{|l|}{ ADF } & \multicolumn{2}{|l|}{ PP } & \multicolumn{3}{|c|}{ Critical values } \\
\hline & Simple & Joint & Simple & Joint & $10 \%$ & $5 \%$ & $1 \%$ \\
\hline Oil & 0.83 & -1.62 & 0.99 & -1.63 & \multirow{4}{*}{-3.22} & \multirow{4}{*}{-3.58} & \multirow{4}{*}{-4.3} \\
\hline Co & 0.49 & -0.52 & -0.34 & & & & \\
\hline GDP & -1.31 & -1.73 & -1.28 & -1.50 & & & \\
\hline RER & 0.83 & -1.62 & 0.99 & -1.64 & & & \\
\hline
\end{tabular}

Table 5.2.Unit Root Test for the First Difference of Variables

\begin{tabular}{|c|c|c|c|c|c|c|c|}
\hline \multirow{3}{*}{$\begin{array}{l}\text { First } \\
\text { Difference }\end{array}$} & \multicolumn{2}{|l|}{ ADF } & \multicolumn{2}{|l|}{ PP } & \multicolumn{3}{|c|}{ Critical values } \\
\hline & & & & & \multirow{2}{*}{$10 \%$} & \multirow{2}{*}{$5 \%$} & \multirow{2}{*}{$1 \%$} \\
\hline & Simple & Joint & Simple & Joint & & & \\
\hline$\Delta O i l$ & -3.77 & -3.73 & -3.41 & -3.35 & \multirow{4}{*}{-3.22} & \multirow{4}{*}{-3.58} & \multirow{4}{*}{-4.3} \\
\hline$\Delta C o$ & -3.91 & -4.64 & -6.85 & -7.62 & & & \\
\hline$\triangle G D P$ & -3.77 & -3.73 & -3.41 & -3.35 & & & \\
\hline$\triangle R E R$ & -3.02 & -3.96 & -5.1 & -6.01 & & & \\
\hline
\end{tabular}

Table5. 3. Two Step Engle-Granger Co-integration Regression

\begin{tabular}{|l|l|l|l|l|l|l|l|}
\hline Variable & Const. & oil & co & $G D P$ & $R^{2}$ & DW & $F$ \\
\hline \multirow{2}{*}{ RER } & 1.98 & 0.19 & -0.023 & -0.33 & 0.90 & 2.09 & 20.01 \\
\hline
\end{tabular}

Numbers in brackets are t-statistics

Table 5.4 . Co-integration Test : Based on

\begin{tabular}{|l|l|lc|}
\hline & $\lambda_{\max }$ & \multicolumn{2}{|l|}{$\begin{array}{l}\text { Critical Values for } \lambda_{\max } \\
90 \%\end{array}$} \\
\hline $\begin{array}{l}H_{0} \quad: r=0 \\
H_{1}: r=1\end{array}$ & 37.23 & 24.99 & 27.42 \\
\hline $\begin{array}{l}H_{0} \quad: \quad r<1 \\
H_{1}: r=2\end{array}$ & 17.5 & 19.02 & 21.12 \\
\hline
\end{tabular}

Table 5.5. Estimated Parameters by using MLE

\begin{tabular}{|l|l|l|l|l|}
\hline Variable & Const. & oil & cO & GDP \\
\hline RER & 1.87 & 0.187 & -0.0199 & -0.313 \\
\hline
\end{tabular}

